\title{
Deteksi Covid-19 pada Citra Sinar-X Dada Menggunakan Pre- Training Deep Autoencoder
}

\author{
Covid-19 Detection on X-Ray Images using Deep Autoencoder as \\ Pre-Training
}

\author{
FADHIL YUSUF RAHADIKA ${ }^{1 *}$, KARINA AMADEA $^{1}$, ADHI SETIAWAN ${ }^{1}$, GRISELDA $^{2}$ \\ ANJELI SIRAIT ${ }^{1}$, NOVANTO YUDISTIRA ${ }^{1}$
}

\begin{abstract}
Abstrak
Deteksi Covid-19 umumnya menggunakan tes laboratorium dengan metode RT-PCR untuk mendapatkan hasil yang akurat. Sayangnya, tes ini membutuhkan waktu yang cukup lama yaitu sekitar 24 jam untuk mendapatkan hasil. Selain menggunakan RT-PCR, beberapa penelitian menunjukkan bahwa deteksi menggunakan citra sinar-X menunjukkan hasil yang cukup akurat dengan waktu prediksi yang lebih cepat. Citra sinar-X yang didominasi warna dalam jangkauan grayscale dapat dikatakan memiliki karakteristik yang berbeda jika dibandingkan dengan citra secara umum, sehingga dalam penelitian ini eksperimen dilakukan terhadap pelatihan untuk kasus klasifikasi citra sinar-X dengan melatih model dari awal (scratch). Namun seringkali model yang dilatih tanpa adanya pretraining menyebabkan model tidak dapat mencapai performa yang cukup baik. Salah satu bentuk metode pretraining yang dapat digunakan adalah penggunaan autoencoder sebagai model untuk rekonstruksi citra. Dalam penelitian ini pelatihan menggunakan pretraining autoencoder menghasilkan akurasi terbaik sebesar $81.78 \%$ dengan tambahan metode CutMix, color manipulation, dan rotation sebagai augmentasi. Kami juga menunjukkan bahwa penambahan pretraining autoencoder secara konsisten dapat meningkatkan akurasi hingga $2.58 \%$ pada model yang dilatih dari awal (scratch).
\end{abstract}

Kata kunci: autoencoder, Covid-19, pretraining, sinar-X.

\begin{abstract}
Covid-19 detection generally uses laboratory tests with the RT-PCR method to get accurate results. Unfortunately, this test takes a long time, which is around 24 hours to get the results. Apart from using the RT$P C R$ test, several studies have shown that detection using X-ray images performs fairly accurate results with a faster prediction time. X-ray images that are constructed by grayscale color have different characteristics compared to the image in common, thus experiments were carried out in this study focused on the training of the $X$-ray image classification model from scratch. But often a model that is trained without pretraining causes the model to not achieve good performance. One form of pretraining method that can be used is by incorporating an unsupervised autoencoder as a model for image reconstruction. In this study, training using pretraining autoencoder achieved the best accuracy of $81.78 \%$ with the addition of the CutMix method, color manipulation, and rotation as augmentation. We also showed that adding autoencoder pretraining can increase accuracy consistently by up to $2.58 \%$ in the model trained from scratch.
\end{abstract}

Keywords: autoencoder, Covid-19, pretraining, X-ray.

\section{PENDAHULUAN}

Pada akhir 2019, coronavirus disease 2019 (Covid-19) menyebar luas di seluruh dunia sehingga Organisasi Kesehatan Dunia (WHO) menetapkan virus ini sebagai pandemi global 
pada awal 2020 (Huang et al. 2020). Jumlah kasus Covid-19 menyebar cepat hingga ke beberapa negara di dunia. Terhitung hingga 3 Maret 2020, secara global dilaporkan 90870 kasus konfirmasi di 72 negara dengan 3112 kematian (CFR 3.4\%) (Kemenkes 2020). Covid-19 memiliki gejala umum antara lain demam (suhu tubuh di atas $38^{\circ} \mathrm{C}$ ), batuk kering, dan sesak napas (WHO 2020). Pada kasus yang lebih parah infeksi Covid-19 bisa menyebabkan komplikasi seperti pneumonia, gagal ginjal, hingga kematian.

Deteksi dini Covid-19 menjadi semakin penting melihat cepatnya penyebaran virus ini dan tingkat berbahayanya. Metode diagnosis umum yang digunakan saat ini adalah RT-PCR yang setidaknya membutuhkan proses 24 jam dan tidak sepenuhnya akurat sehingga bisa memerlukan tes RT-PCR kedua untuk memastikan diagnosis (Islam et al. 2020). Cara lainnya yaitu dengan melakukan pemindaian gambar sinar-X dan computed tomography (CT) scan, kedua pemindaian gambar ini dapat membantu dalam menemukan diagnosis dini virus ini dengan lebih cepat dan akurat (Dansana et al. 2020). CT scan memiliki keunggulan lebih cepat dalam penghasilan informasi namun biayanya yang mahal dan dapat meningkatkan risiko kanker dibandingkan dengan prosedur pencitraan sinar-X konvensional (foto rontgen) yang lebih umum. Di sisi lain, sinar-X memiliki keunggulan yaitu biaya yang lebih terjangkau dan banyak tersedia di fasilitas kesehatan pada umumnya (Dai et al. 2020).

Sebuah pemanfaatan sistem kecerdasan buatan akan membantu proses deteksi dini Covid19 dengan mengklasifikasikan hasil gambar pemindaian sinar-X sehingga akan membantu petugas medis dalam mempercepat waktu diagnosis dan mendapatkan hasil yang akurat. Namun dengan keterbatasan data sinar-X Covid-19 yang sudah terlabeli saat ini membuat sistem kecerdasan buatan hanya bisa belajar dari data yang terbatas. Di sisi lain autoencoder dapat ditambahkan sebagai metode pretraining secara unsupervised untuk mengkalibrasi bobot awal jaringan syaraf tiruan (JST). Autoencoder merupakan salah satu jenis JST yang dapat digunakan untuk mengurangi dimensi fitur (dimensionality reduction) dan merekonstruksinya kembali menjadi bentuk awalnya. Keuntungan dari unsupervised learning di antaranya yaitu tidak membutuhkan pelabelan untuk melatih layer konvolusi, sedangkan data ke depannya akan semakin bertambah dan akan memakan usaha serta biaya yang tinggi untuk melabeli dan melatih layer konvolusi tersebut. Pada penelitian ini, dari hasil pelatihan autoencoder hanya digunakan pada bagian encoder saja yang akan di-finetuning untuk proses klasifikasi citra sinar$\mathrm{X}$ untuk mendeteksi seseorang terserang Covid-19, pneumonia, atau sehat.

Ozturk et al. (2020) melakukan penelitian dan dataset yang sama menggunakan model DarkNet dengan menerapkan 17 layer konvolusi dan menggunakan filter yang berbeda pada setiap layer mendapatkan akurasi $87.02 \%$ untuk multiclass classfication yaitu Covid-19, pneumonia, dan normal. Yudistira et al. (2020) juga melakukan penelitian serupa dengan membandingkan antara tiga model yaitu ShuffleNet, EfficientNet, dan ResNet50 dengan CNN FullConv dan mendapatkan akurasi sebesar $86.93 \%$ pada model ShuffleNet dengan jumlah parameter model yang lebih kecil 18.55 kali dari EfficientNet dan 22.36 kali lebih kecil dari ResNet50. Minaee et al. (2020) melakukan penelitian serupa menggunakan citra X-ray dada dan perbandingan terhadap beberapa arsitektur yang berbeda yaitu ResNet18, ResNet50, SqueezeNet, dan DenseNet-121. Hasil evaluasi terhadap beberapa model tersebut mendapatkan nilai sensitivity rate kurang lebih $98 \%$ dan specificity rate $90 \%$.

Perbedaan yang ada pada penelitian sebelumnya dengan penelitian ini adalah penggunaan model atau arsitektur yang digunakan, selain itu pada penelitian terdahulu banyak yang sepenuhnya hanya menerapkan supervised learning (Abbas et al. 2021; Taresh et al. 2021; Turkoglu 2021). Penggunaan unsupervised learning pada penelitian ini akan memberikan keuntungan karena tidak membutuhkan pelabelan untuk melatih layer konvolusi. Namun demikian, jenis unsupervised learning lebih menantang karena seringkali menghasilkan akurasi yang lebih rendah daripada supervised learning karena tidak adanya supervisi. Penelitian sebelumnya tentang model unsupervised learning berbasis stacked-autocencoder untuk deteksi Covid-19 hanya dilatih pada set data citra CT dengan 2 kelas (Li et al. 2020). Sedangkan pada 
penelitian ini, autoencoder dilatih pada citra X-ray dengan 3 kelas yaitu pneumonia, Covid-19, dan normal yang lebih menarik untuk dieksplorasi lebih lanjut.

\section{METODE}

\section{Dataset dan Preprocessing}

Pada penelitian ini, dataset yang digunakan adalah citra sinar-X Covid-19 sebanyak 1125 citra yang terbagi atas 3 kelas. Pada 1125 citra tersebut terdapat 125 citra pasien positif Covid19, 500 citra normal, dan 500 citra pneumonia. Dataset tersebut dapat diunduh di alamat https://github.com/muhammedtalo/covid-19 (Ozturk et al. 2020). Contoh dari dataset ini dapat dilihat pada Gambar 1 yang menunjukkan citra paru-paru terpapar Covid-19, normal, dan terpapar pneumonia.

Penelitian ini menggunakan dua tahap preprocessing, yaitu normalisasi dan augmentasi data. Normalisasi data digunakan untuk membuat nilai data berada dalam suatu rentang tertentu dengan tujuan membantu proses pelatihan menjadi jauh lebih cepat. Augmentasi data digunakan untuk meningkatkan variasi data tambahan yang dapat mengoptimalkan performa pelatihan dari model deep learning (Wang dan Perez 2017). Pada penelitian ini, normalisasi data menggunakan nilai rata-rata dan standar deviasi secara manual, sedangkan augmentasi data menggunakan metode transformasi data yaitu fungsi ColorJitter atau pengaturan warna HSV dan fungsi RandomHorizontalFlip atau rotasi.

\section{Model Arsitektur}

Convolutional neural network $(\mathrm{CNN})$ adalah salah satu metode klasifikasi dalam bidang deep learning yang memiliki operasi konvolusi untuk mengekstraksi fitur dari data input. CNN terbagi atas dua tahapan utama yaitu feature learning dan classification. Pada tahapan pertama terdiri atas convolution layer, ReLU (fungsi aktivasi), dan pooling layer. Sedangkan pada tahap kedua terdiri atas flatten, fully-connected layer, dan hasil prediksi. Pada setiap bagian tahapan terdapat dua proses utama, yaitu feed-forward dan backpropagation (O'Shea dan Nash 2015).

Ada 2 model arsitektur CNN yang digunakan dalam penelitian ini yang bertujuan untuk merekonstruksi citra sinar-X Covid-19, yaitu model AlbuNet dan residual neural network (ResNet). Model AlbuNet merupakan modifikasi dari model LinkedNet dengan model ResNet sebagai versi dari proses autoencoder (Shvets et al. 2018). ResNet merupakan salah satu arsitektur yang cukup populer dan memiliki berbagai macam jenis arsitektur, mulai dari 18, 34, 50, 101, sampai 152 layer (He 2016). Berdasarkan jenis arsitektur tersebut, ResNet-18 yang hanya memiliki 18 layer dipilih sebagai model untuk melakukan proses autoencoder karena keterbatasan hardware dan waktu pengerjaan.

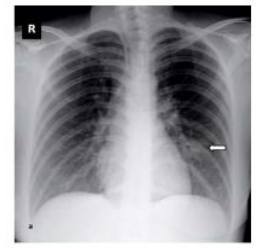

(1)

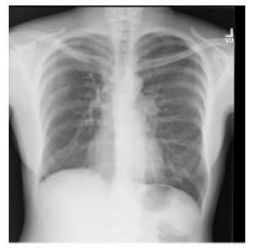

(2)

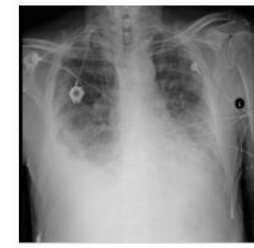

(3)

Gambar 1 Citra paru-paru yang (1) terpapar Covid-19, (2) normal, (3) terpapar pneumonia (Yudistira et al. 2020)

\section{Mixed Sample Data Augmentation}

Pada pelatihan model JST sering kali ditemukan fenomena overfitting, yaitu model terlalu fokus belajar pada data latih yang minim variasi polanya sehingga ketika dilakukan pengujian pada data uji akan banyak terdapat kesalahan jika terdapat data dengan pola di luar variasi data latih. Masalah overfitting ini salah satunya dapat ditangani dengan cara menambah metode 
augmentasi terhadap data salah satunya dengan mixed sample data augmentation (MSDA) yang menggabungkan fitur-fitur yang dimiliki beberapa data menjadi satu.

a. Mixup. Mixup bekerja dengan mengombinasikan warna dari dua citra dan labelnya. Pada beberapa eksperimen yang telah diterapkan pada kumpulan data ImageNet-2012, CIFAR10, CIFAR-100, Google, dan UCI menunjukkan bahwa Mixup dapat meningkatkan kemampuan generalisasi arsitektur JST yang canggih. Penelitian tersebut juga menemukan bahwa mixup dapat mengurangi pengenalan label yang tidak lengkap dan menstabilkan pelatihan adversarial generative networks (Zhang et al. 2018). Ilustrasi hasil augmentasi mixup dapat dilihat pada Gambar 2.

b. CutMix. CutMix merupakan salah satu jenis augmentasi data citra yang pada prosesnya melakukan cut dan paste pada bagian acak piksel pada sebuah data latih citra. CutMix diusulkan untuk menggantikan salah satu metode regional dropout yang mengganti suatu bagian dari citra dengan piksel hitam. Hal ini bisa menghilangkan informasi penting yang terdapat dalam citra tersebut. Oleh karena itu daripada menghilangkan salah satu bagian dari citra lebih baik mengganti bagian yang dihilangkan tersebut dengan citra yang lain secara proporsional agar suatu model bisa lebih fokus pada bagian yang tidak terlalu diskriminatif pada objek (Yun et al. 2019). Ilustrasi hasil augmentasi CutMix dapat dilihat pada Gambar 3.

c. FMix. FMix adalah salah satu bentuk metode augmentasi dengan teknik masking yang dihasilkan dari Fourier space secara acak yang berbentuk tidak teratur namun nilainya berkelanjutan sehingga fitur tersebut tetap terjaga korelasinya dengan fitur di sekitarnya, khususnya untuk data yang berjenis citra yang tiap piksel dapat berkorelasi kuat dengan piksel di sekitarnya. Pada penelitian yang sudah dilakukan sebelumnya, secara umum FMix dapat menghasilkan model dengan performa yang lebih baik dibanding metode MSDA yang sudah ada sebelumnya, seperti Mixup dan CutMix (Harris et al. 2020). Ilustrasi hasil augmentasi FMix dapat dilihat pada Gambar 4.
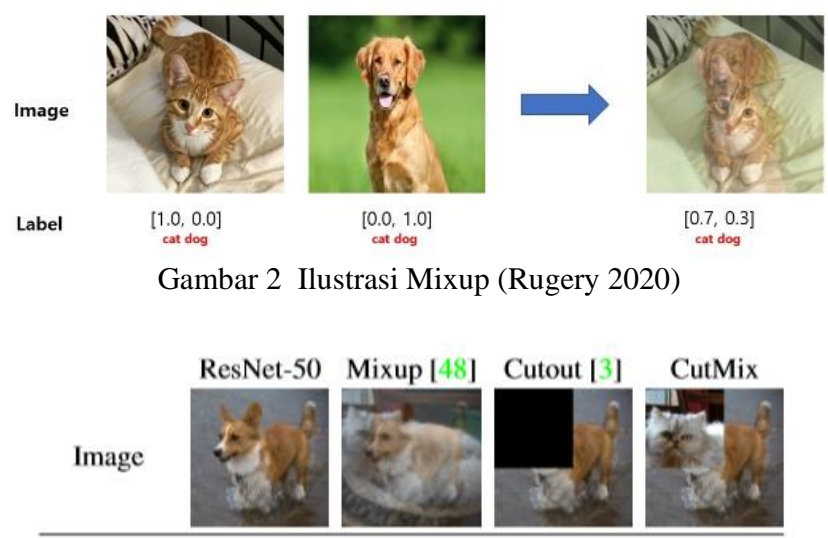

Gambar 3 Ilustrasi perbedaan hasil augmentasi Mixup, Cutout, dan CutMix (Yun et al. 2019)

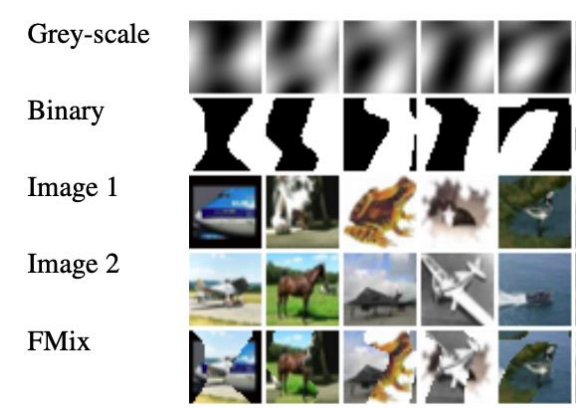

Gambar 4 Ilustrasi FMix (Harris et al. 2020) 


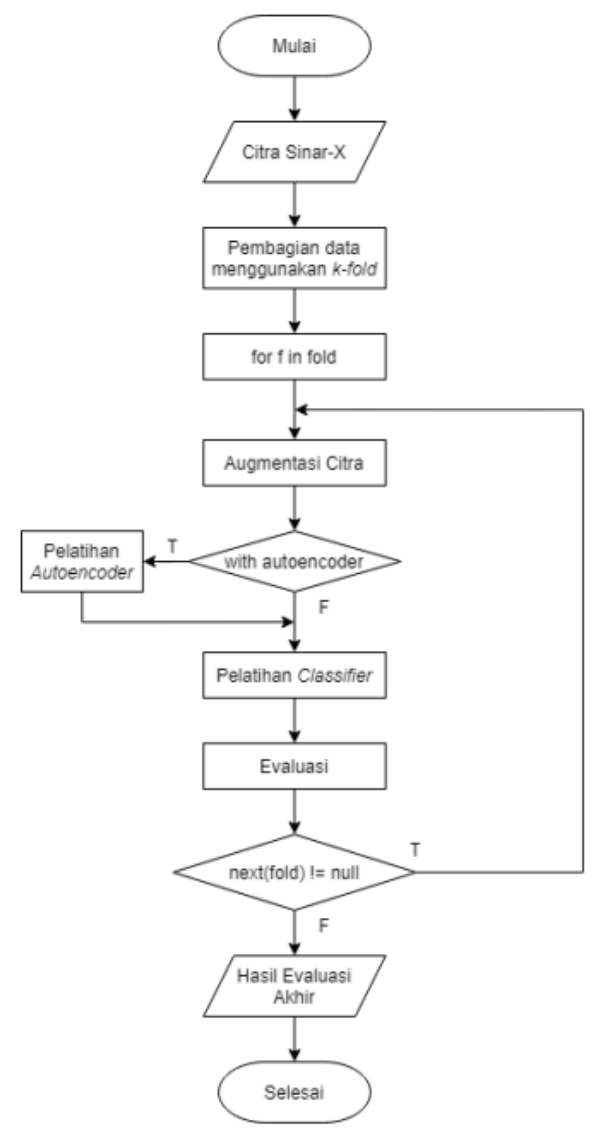

Gambar 5 Flowchart tahap pelatihan

\section{Tahap Pelatihan}

Pada penelitian ini, pelatihan model dilakukan dengan dan tanpa arsitektur autoencoder dengan pembagian dataset menggunakan metode $k$-fold cross validation sebelum dilakukannya pemrosesan untuk augmentasi, pelatihan, dan classifier. Ilustrasi tahapan pelatihan dapat dilihat pada Gambar 5.

Pelatihan model dilakukan menggunakan platform Google Colab dengan akselerasi graphical processing unit (GPU) untuk mempercepat proses komputasi. Proses pelatihan model autoencoder sebagai pretraining memakan waktu sekitar 8 menit, sedangkan proses pelatihan model klasifikasi untuk 1-fold memakan waktu sekitar 30 menit dengan jumlah 100 epoch. Platform ini menyediakan perangkat keras dengan spesifikasi 2 vCPU @ 2.2Ghz, 13 GB RAM, dan GPU Nvidia K80/T4/P4/P100. Tahap pelatihan model menggunakan platform Google Colab juga bertujuan untuk mensimulasikan proses inferensi untuk deteksi dini menggunakan platform yang mudah dijangkau. Perangkat lunak yang digunakan pada penelitian ini yaitu Python 3.6 dan Pytorch 1.8.

\section{a. Tahap Pelatihan Autoencoder}

Autoencoder adalah jenis arsitektur JST yang terdiri atas bagian encoder untuk ekstraksi fitur ke dimensi yang lebih kecil dan decoder untuk merekonstruksi ke ukuran aslinya. Kami menggunakan jenis task rekonstruksi citra untuk tahap pelatihan autoencoder dalam penelitian ini. Pembelajaran rekonstruksi citra adalah pelatihan yang bertujuan untuk mempelajari data masukan dan merekonstruksi terhadap data masukan tersebut sebagai pengurangan dimensi fitur.

Pada penelitian ini, digunakan arsitektur AlbuNet sebagai autoencoder yang terdiri dari lapisan sebagai berikut. Lapisan input: lapisan data citra dengan parameter ditentukan oleh ukuran data masukan citra. Kombinasi lapisan konvolusi dan pooling: lapisan konvolusi menghasilkan feature map dari data input, sedangkan lapisan pooling membantu dalam mengurangi overfit. Parameter lapisan ini dapat dilihat pada Tabel . Ilustrasi secara 
keseluruhan dari arsitektur autoencoder yang kami gunakan pada penelitian ini dapat dilihat pada Gambar 6.

\section{b. Tahap Pelatihan Classifier}

Pelatihan pada tahap ini adalah pelatihan akhir secara supervised setelah pelatihan autoencoder. Pada pelatihan ini, hanya menggunakan bagian encoder saja dari autoencoder untuk mengklasifikasikan data. Tahap setelah diambil encoder-nya saja, jaringan kembali ke bentuk awalnya yaitu ResNet-18. ResNet adalah arsitektur berbasis CNN dengan penambahan adanya jalur shortcut yang dinamakan residual connection di antara blok CNN untuk mengatasi masalah vanishing gradient (He et al. 2016). Ilustrasi dari residual connection pada arsitektur ResNet-18 dapat dilihat pada Gambar 7.

Tabel 1 Arsitektur autoencoder

\begin{tabular}{|c|c|c|}
\hline Nama layer & Ukuran output & 18-layer \\
\hline conv1 & $112 \times 112$ & $\begin{array}{c}7 \times 7,64 \text { filter, stride } 2, \text { padding } 3 \\
3 \times 3 \text { max pooling, stride } 2 \text {, padding } 1\end{array}$ \\
\hline conv2 & $56 \times 56$ & {$\left[\begin{array}{l}3 \times 3,64 \\
3 \times 3,64\end{array}\right] \times 2$} \\
\hline conv3 & $28 \times 28$ & {$\left[\begin{array}{l}3 \times 3,128 \\
3 \times 3,128\end{array}\right] \times 2$} \\
\hline conv4 & $14 \times 14$ & {$\left[\begin{array}{l}3 \times 3,256 \\
3 \times 3,256\end{array}\right] \times 2$} \\
\hline conv5 & $7 \times 7$ & {$\left[\begin{array}{l}3 \times 3,512 \\
3 \times 3,512\end{array}\right] \times 2$} \\
\hline decoder 1 & $14 \times 14$ & {$\left[\begin{array}{c}\text { conv } 1 \times 1,256 \\
\text { trans } 4 \times 4, \text { stride } 2 \\
\text { conv } 1 \times 1,256 \\
\text { conv } 1 \times 1,128\end{array}\right]$} \\
\hline decoder2 & $28 \times 28$ & {$\left[\begin{array}{c}\text { trans } 4 \times 4, \text { stride } 2 \\
\text { conv } 1 \times 1,128\end{array}\right]$} \\
\hline decoder3 & $56 \times 56$ & {$\left[\begin{array}{c}\text { trans } 4 \times 4, \text { stride } 2 \\
\text { conv } 1 \times 1,64 \\
\text { conv } 1 \times 1,64\end{array}\right]$} \\
\hline decoder 4 & $112 \times 112$ & {$\left[\begin{array}{c}\text { trans } 4 \times 4, \text { stride } 2 \\
\text { conv } 1 \times 1,64\end{array}\right]$} \\
\hline decoder5 & $224 \times 224$ & trans $3 \times 3$, stride 2 \\
\hline decoder6 & $224 \times 224$ & $\operatorname{conv} 3 \times 3,32$ \\
\hline decoder7 & $224 \times 224$ & $\operatorname{conv} 2 \times 2,3$ \\
\hline
\end{tabular}

Proposed Autoencoder Architecture Based on AlbuNet

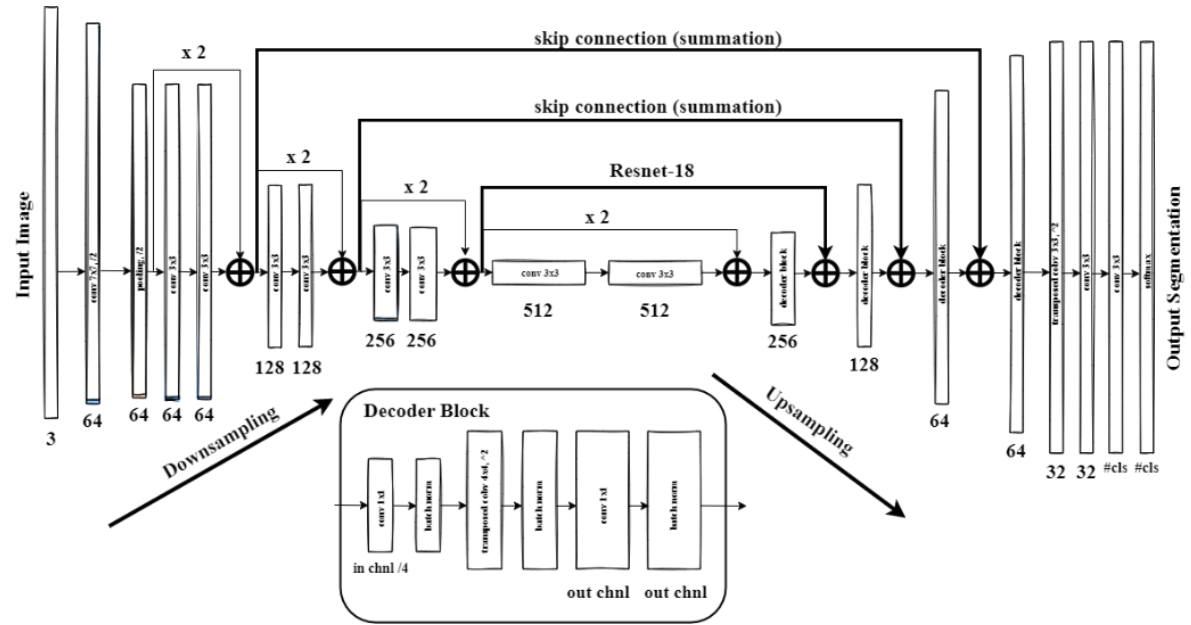

Gambar 6 Ilustrasi arsitektur autoencoder penelitian ini yang berdasar dari arsitektur AlbuNet (Shvets et al. 2018) 


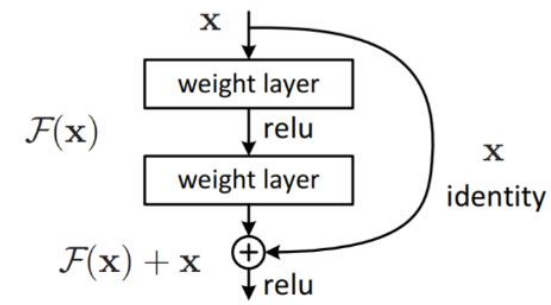

Gambar 7 Ilustrasi arsitektur ResNet (He et al. 2015)

Tabel 2 Hasil eksplorasi augmentasi

\begin{tabular}{cccccc}
\hline HFlip & Bright 0.25 & Saturation 0.25 & Hue 0.1 & Rotate $15^{\circ}$ & Akurasi \\
\hline & & & & 0.7973 \\
& & & $\checkmark$ & 0.8124 \\
& & & $\checkmark$ & & 0.7902 \\
& $\checkmark$ & & & 0.8036 \\
$\checkmark$ & & & & 0.7724 \\
& & & & & 0.7876 \\
& & & & & \\
& & & &
\end{tabular}

Tabel 3 Hasil eksplorasi mixed sample data augmentation (MSDA)

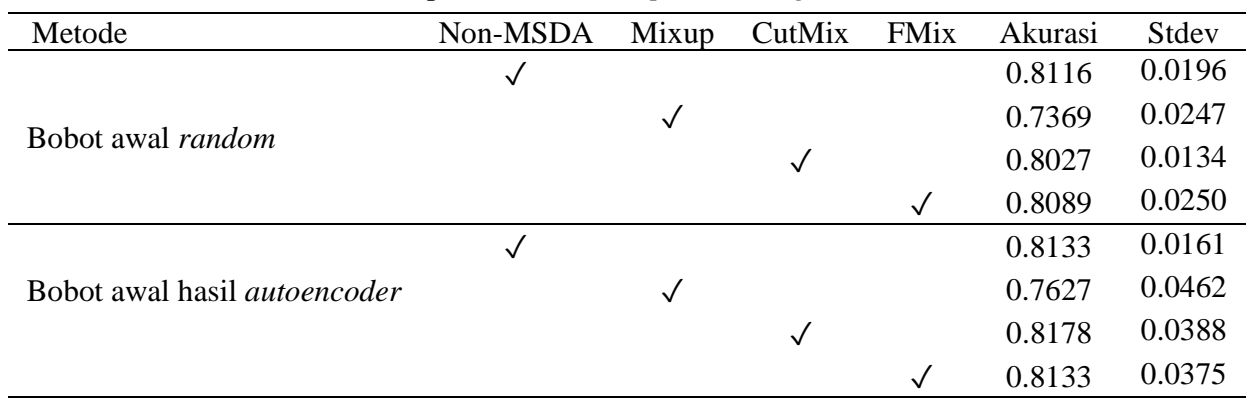

\section{HASIL DAN PEMBAHASAN}

Pada penelitian ini dilakukan percobaan untuk menerapkan autoencoder sebagai pretraining dalam kasus klasifikasi citra sinar-X dada yang mempunyai 3 kategori, yaitu normal, pneumonia, dan Covid-19. Pada tahap sebelumnya telah dilakukan pelatihan terhadap model AlbuNet yang menggunakan Resnet-18 sebagai encoder-nya dengan batch size sebesar 256, learning rate sebesar $1 \times 10^{-4}$, dan Adam sebagai optimizer.

Pengujian model tersebut dilakukan percobaan menggunakan validasi silang 5. Pada setiap percobaan tersebut menggunakan perbandingan data latih dan data uji dalam setiap percobaan adalah sebesar 80:20. Pada penelitian ini juga diterapkan augmentasi tipe putar (rotate), balik (horizontal flip), dan pengaturan warna (saturation, brigthness, hue) untuk meningkatkan variasi pola citra. Dalam penerapannya, didapatkan hasil bahwa akurasi model akan mengalami kenaikan terbesar jika menerapkan gabungan dari tipe augmentasi rotate dan saturation seperti yang terlihat pada Tabel .

Pada saat dilakukan percobaan, metode augmentasi yang digunakan pada percobaan terakhir bertambah kompleks, sehingga khusus pada percobaan tersebut kami menaikkan epoch-nya dari 25 menjadi 50. Tidak hanya augmentasi, kami juga melakukan normalisasi pada data menggunakan rataan dan standar deviasi dari data latih tiap fold cross validation.

Eksplorasi juga dilakukan pada data dengan menerapkan metode MSDA untuk melokalisir fitur-fitur yang terdapat pada data dengan menggunakan 100 epoch. Pada eksplorasi ini didapatkan akurasi terbesar dengan menggunakan MSDA jenis CutMix seperti yang terlihat pada Tabel . Pada hasil tersebut juga dapat membuktikan bahwa metode pre-training dengan autoencoder menunjukkan peningkatan performa pada dataset citra sinar-X dibandingkan menggunakan bobot awal secara acak. Rata-rata nilai loss yang dihasilkan dari eksplorasi 
autoencoder dari tiap fold dengan Cutmix yaitu sebesar 0.486. Grafik nilai loss dan akurasi pada tiap fold selama pelatihan secara berturut-turut dapat dilihat Gambar 8 dan Gambar 9.

Pada Tabel 4 dapat dilihat bahwa hasil prediksi Covid-19 dan menghasilkan prediksi yang benar ada 104 data dari 125 data. Lima data terprediksi sebagai normal, dan 16 data terprediksi pneumonia. Kemudian pada bagian hasil prediksi normal, ada 428 data yang terprediksi secara benar dan 72 data salah prediksi sebagai pneumonia. Selanjutnya pada bagian pneumonia ada 390 data yang terprediksi secara benar, 104 data salah prediksi sebagai normal, dan enam data terprediksi salah sebagai Covid-19.

Hasil pengujian model autoencoder dengan akurasi terbaik pada kasus klasifikasi dirangkum dalam confusion matrix agar selanjutnya dapat diolah menjadi metrik yang lebih spesifik seperti precision, recall, dan fl-score. Confusion matrix pada Tabel juga dapat menunjukkan bahwa model tidak dapat memisahkan kelas citra sinar-X dada kategori normal dan pneumonia dengan baik. Hal ini dapat dilihat dari false positive yang cukup besar di antara dua kelas ini yang bisa disebabkan karena kemiripan fitur di antara dua kelas tersebut dan model yang sudah kami latih tidak dapat membedakannya berdasarkan fitur yang telah diekstraksi. Berdasarkan Tabel juga, dapat dilihat bahwa model sudah cukup baik mengklasifikasikan data dengan label Covid-19 dengan false negative yang lebih kecil terhadap dua kelas lainnya.
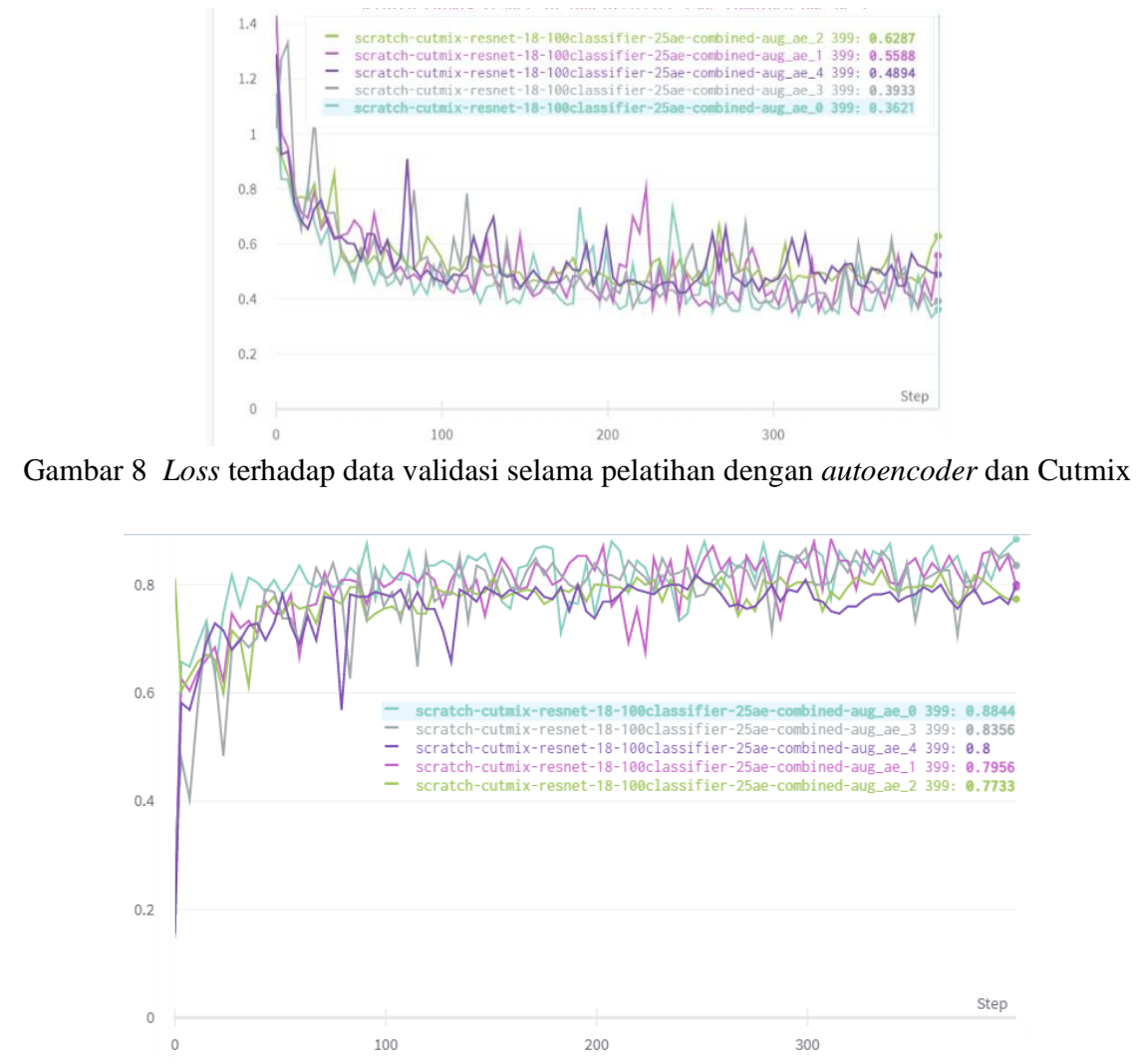

Gambar 9 Akurasi terhadap data validasi selama pelatihan dengan autoencoder dan Cutmix

Tabel 4 Confusion Matrix AlbuNet-18 + autoencoder + Cutmix dengan 5-fold cross validation

\begin{tabular}{lccc}
\hline & Covid-19 & normal & pneumonia \\
\hline Covid-19 & 104 & 5 & 16 \\
normal & 0 & 428 & 72 \\
pnumonia & 6 & 104 & 390 \\
\hline
\end{tabular}

Tabel 5 Perhitungan metrik hasil pengujian

\begin{tabular}{lccc}
\hline Kelas & Precision & Recall & F1-score \\
\hline Covid-19 & $94.55 \%$ & $83.20 \%$ & $88.51 \%$ \\
normal & $79.70 \%$ & $85.60 \%$ & $82.54 \%$ \\
penumonia & $81.59 \%$ & $78.00 \%$ & $79.75 \%$ \\
\hline
\end{tabular}


Hasil pengolahan confusion matrix menjadi metrik yang spesifik disajikan pada Tabel . Dari tabel tersebut dapat dihitung juga macro-precision sebesar $85.28 \%$, macro-recall sebesar $82.27 \%$, dan macro-F1 sebesar $83.6 \%$ yang dihitung dari rata-rata metrik di tiap kelas.

\section{SIMPULAN}

Hasil eksperimen yang telah dilakukan terhadap metode augmentasi gabungan antara manipulasi warna pada channel saturation dan pemutaran citra menujukkan peningkatan akurasi mencapai $2.05 \%$ terhadap baseline yang dilatih tanpa menggunakan metode augmentasi. Selain itu, dalam eksperimen penggunaan MSDA pada citra sinar-X didapatkan hasil bahwa pengaplikasian Mixup selalu menunjukkan penurunan performa baik menggunakan autoencoder ataupun tanpa menggunakan autoencoder, sedangkan CutMix dan FMix juga menunjukkan penurunan performa namun hanya pada pelatihan model tanpa menggunakan autoencoder sebagai pretraining. Secara umum, pelatihan menggunakan autoencoder sebagai pretraining pada kasus klasifikasi citra sinar-X untuk deteksi Covid-19 dan pneumonia menunjukkan peningkatan akurasi secara konsisten terhadap seluruh konfigurasi pengujian tanpa autoencoder. Peningkatan performa penggunaan autoencoder sebagai pretraining mulai dari $0.17 \%$ pada hasil pelatihan tanpa MSDA yang naik dari $81.16 \%$ pada pelatihan tanpa autoencoder ke $81.33 \%$ pada pelatihan dengan autoencoder. Puncaknya dapat dilihat pada pelatihan dengan MSDA Mixup yang naik dari $73.69 \%$ pada pelatihan tanpa autoencoder ke $76.27 \%$ pada pelatihan dengan autoencoder.

\section{DAFTAR PUSTAKA}

Abbas A, Abdelsamea MM, Gaber MM. 2021. Classification of Covid-19 in chest X-ray images using DeTraC deep convolutional neural network. Applied Intelligence. 51(2): 854-864. doi: 10.1007/s10489-020-01829-7.

Dai WC, Zhang HW, Yu J, Xu HJ, Chen H, Luo SP, Zhang H, Liang LH, Wu XL, Lei Y, et al. 2020. CT imaging and differential diagnosis of Covid-19. Canadian Association of Radiologists Journal. 71(2): 195-200. doi: 10.1177/0846537120913033.

Dansana D, Kumar R, Bhattacharjee A, Hemanth DJ, Gupta D, Khanna A, Castillo O. 2020. Early diagnosis of Covid-19-affected patients based on X-ray and computed tomography images using deep learning algorithm. Soft Comput. doi: 10.1007/s00500-020-05275-y.

Harris E, Marcu A, Painter M, Niranjan M, Prugel-Bennet A, Hare J. 2020. FMix: enhancing mixed sample data augmentation. ArXiv Preprint. https://arxiv.org/abs/2002.12047.

He K, Zhang X, Ren S, Sun J. 2016. Deep residual learning for image recognition. Di dalam: IEEE Conference on Computer Vision and Pattern Recognition (CVPR). hlm 770-778.

Huang C, Wang Y, Li X, Ren L, Zhao J, Hu Y, Zhang L, Fan G, Xu J, Gu X, et al. 2020. Clinical features of patients infected with 2019 novel coronavirus in Wuhan, China. The Lancet. 395(10223): 497-506. doi: 10.1016/S0140-6736(20)30183-5.

Islam N, Ebrahimzadeh S, Salameh J-P, Kazi S, Fabiano N, Treanor L, Absi M, Hallgrimson Z, Leeflang MMG, Hooft L, et al. 2020. Thoracic imaging tests for the diagnosis of Covid-19. Cochrane Database of Systematic Reviews. (3): CD013639. doi: 10.1002/14651858.CD013639.pub4.

[Kemenkes] Kementrian Kesehatan RI. 2020. Pedoman Pencegahan dan Pengendalian Covid19. Ed ke-3. Jakarta: Kementerian Kesehatan RI.

Li D, Fu Z, Xu J. 2020. Stacked-autoencoder-based model for Covid-19 diagnosis on CT images. Applied Intelligence. 51(5): 2805-2817. doi: 10.1007/s10489-020-02002-w 
Minaee S, Kafieh R, Sonka M, Yazdani S, Soufi GJ. 2020. Deep-Covid: predicting Covid-19 from chest X-ray images using deep transfer learning. Medical Image Analysis. 65: 101794. doi: 10.1016/j.media.2020.101794.

O’Shea K, Nash R. 2015. An introduction to convolutional neural networks. arXiv Preprint. https://arxiv.org/abs/1511.08458.

Ozturk T, Talo M, Yildirim EA, Baloglu UB, Yildirim O, Acharya UR. 2020. Automated detection of Covid-19 cases using deep neural networks with X-ray images. Computers in Biology and Medicine. (121): 103792. doi: 10.1016/j.compbiomed.2020.103792.

Perez L, Wang J. 2017. The effectiveness of data augmentation in image classification using deep learning. ArXiv Prerint. https://arxiv.org/abs/1712.04621.

Rugery P. 2020. Explanation of YOLO V4 a one stage detector. https://becominghuman.ai /explaining-yolov4-a-one-stage-detector-cdac0826cbd7

Shvets AA, Iglovikov VI, Rakhlin A, Kalinin AA. 2018. Angiodysplasia detection and localization using deep convolutional neural networks. Di dalam: IEEE International Conference on Machine Learning and Applications (ICMLA). hlm 612-617. doi: 10.1109/ICMLA.2018.00098.

Taresh MM, Zhu N, Ali TAA, Hameed AS, Mutar ML. 2021. Transfer learning to detect Covid19 automatically from X-ray images using convolutional neural networks. International Journal of Biomedical Imaging. doi: 10.1155/2021/8828404.

Turkoglu M. 2021. CoviDetectioNet: Covid-19 diagnosis system based on X-ray images using features selected from pre-learned deep features ensemble. Applied Intelligence. 51(3): 1213-1226. doi: 10.1007/s10489-020-01888-w.

[WHO] World Health Organization. 2020. Coronavirus disease (Covid-19). [diakses 2020 Des 6]. https://www.who.int/emergencies/diseases/novel-coronavirus-2019/question-andanswers-hub/q-a-detail/coronavirus-disease-covid-19.

Yudistira N, Widodo AW, Rahayudi B. 2020. Deteksi Covid-19 pada citra sinar-x dada menggunakan deep learning yang efisien. Jurnal Teknologi Informasi dan Ilmu Komputer. 7(6): 1289-1296. doi: 10.25126/jtiik.202073651.

Yun S, Han D, Oh SJ, Chun S, Choe J, Yoo Y. 2019. CutMix: regularization strategy to train strong classifiers with localizable features. Di dalam: IEEE/CVF International Conference on Computer Vision (ICCV). hlm 6023-6032.

Zhang H, Cisse M, Dauphin YN, Lopez-Paz D. 2018. Mixup: beyond empirical risk minimization. Arxiv Preprint. https://arxiv.org/abs/1710.09412. 